\title{
Influencing the anticorrosion efficiency of pigments based on zinc ferrite by conductive polymers
}

\section{Ovlivnění antikorozní účinnosti pigmentů na bázi zinkferitu vodivými polymery}

Nechvílová K., Kalendová A.

Institute of Chemistry and Technology of Macromolecular Materials, University of Pardubice

E-mail: Katerina.Nechvilova@student.upce.cz

Generally, organic coatings which contain zinc ferrites are able to protect metal substrate, most often low-carbon steel, by inhibition mechanism. Conductive polymers are using a system of conjugated double-bonds to transfer a charge over the chain thereby providing their own electrical conductivity in the organic coatings. The charge from the chain in combination with the iron substrate generates electrons to the formation of passivation products on the surface of paint film. This paper is focused on combination of zinc ferrite with conductive polymer and using of synergic effect of these two components. The organic coatings were formulated from hematite and specularite on pigments concentration line 5, 10, 20 and $25 \mathrm{wt} \%$ for better recognizing of the effectiveness of zinc ferrite component. The content of the conductive polymer was consistently set at 3 wt.\% in each organic coating. A solvent-based epoxy-ester resin was used as a binder. The physico-mechanical and corrosion tests were performed for all samples. The corrosion signs were evaluated on the surface of coating and also on the surface of metal substrate. In the end, the efficiency was compared alone zinc ferrite and alone polymers and also their combinations.

\section{INTRODUCTION}

Material protection from degradation and the related area of material corrosion have been among the most widely discussed topics for a number of decades [1]. Degradation of materials by corrosion processes brings about financial losses which are estimated at $3 \%$ to $5 \%$ of the gross domestic product in developed countries. In this manner the Czech Republic lost approximately 140 million Czech crowns in 2016. Surface protection against corrosion effects is imperative for an efficient use of steel and products made of it. Atmospheric corrosion is responsible for $80 \%$ of degradation of such materials. One of the feasible material protection methods consists in the use of organic coatings, i.e. systems consisting of an organic binder and an anticorrosion pigments [2].
Obecně, organické povlaky s obsahem zinkferitů velmi často vykazuji inhibični mechanismus ochrany podkladového kovu nejčastěji nizko uhlikové ocele. Vodivé polymery využivaji systém konjugovaných dvojných vazeb $k$ přenosu náboje přes řetězec, čimž zajištuji $v$ organických povlacích svou vlastni elektrickou vodivost. Přenosem náboje na tomto řtězci, $v$ kombinaci se substrátem na bázi železa generujicího elektrony, vznikaji na povrchu nátěrového filmu produkty pasivace. Tento př́spěvek je zaměřen na kombinaci zinkferitu a vodivého polymeru s využitím synergického efektu těchto dvou složek. Pro porovnáni účinnosti zinkferitové složky byly nátěrové hmoty formulovány z hematitu i spekularitu při koncentraci pigmentu 5, 10, 20 a $25 \mathrm{hm} \%$. Obsah vodivého polymeru byl jednotně stanoven na $3 \mathrm{hm} \%$ v každé nátěrové hmotě. Jako vrchni nátěr bylo využito směsi $\mathrm{TiO}_{2}$ a $\mathrm{CaCO}_{3} v$ epoxyesterové pryskyřici pro přibliženi se reálných vzorküm. U všech organických povlaků byly provedeny fyzikálně-mechanické testy. Nejdůležitějš́i zkouškou bylo vystavení vzorků v prostředí simulujici prümyslové znečištěni s obsahem oxidu siřičitého. U všech vzorků byly vyhodnoceny korozni projevy na povrchu organického povlaku i na povrchu ocelového panelu. Na závěr byla porovnána účinnost samotných zinkferitů $i$ vodivých polymerů a jejich vzájemné kombinace. Vodivé polymery zvyšovaly odolnost organických povlakì.

Such systems are subject to constant legal supervision to prevent the use of toxic and potentially harmful pigments. To this end, scientific research has been focussing, among other things, on conductive polymers usable in paints possessing anticorrosion properties [3]. Appropriate and efficient anticorrosion protection can reduce or fully eliminate the costs spent on the repair or replacement of corroded materials [4]. Spinel type pigments possessing the general formula $\mathrm{AB}_{2} \mathrm{O}_{4}$ where $\mathrm{A}$ is $\mathrm{Mg}, \mathrm{Zn}, \mathrm{Co}, \mathrm{Fe}$, $\mathrm{Mn}$ or $\mathrm{Cu}$ and $\mathrm{B}$ is $\mathrm{Al}, \mathrm{Fe}, \mathrm{Cr}$, $\mathrm{Co}$ or Ti are promising in this respect [5]. For instance, zinc ferrites $\mathrm{ZnFe}_{2} \mathrm{O}_{4}$ are well known. The anticorrosion effect of spinel pigments is based on the formation of zinc or calcium soaps by reaction with a suitable binder [6]. As a result, the paint film's mechanical properties are improved while its permeability for the aggressive environment is reduced. 
The spinel type pigment gives rise to a barrier effect as well to a neutralisation effect, if the corrosive substances are transformed to a state that does not endanger the metal [7]. Spinel pigments also exhibit neutralising properties because their aqueous extracts have $\mathrm{pH}=9.8$, owing to which they neutralise the acid binders and shift the $\mathrm{pH}$ to a range that does not promote corrosion. In addition, spinel pigments are physiologically harmless and hence, can be used to replace existing toxic anticorrosion pigments [8]. An their combination with conductive polymers, which exhibit their own electric conductivity owing to their system of conjugated double bonds, is convenient in that it combines the protective effects described above and protective effects based on the electrochemical mechanism. Also, the conductive polymers are environmentally harmless, are easy to prepare, and the input materials are readily available [9]. So, the major benefit provided by conductive polymers is in the fact that they provide high corrosion protection even if present in small proportions [10].

\section{EXPERIMENTAL}

The conductive polymers were prepared by the typical oxopolymerisation reaction in laboratory conditions. $\mathrm{H}_{3} \mathrm{PO}_{4}(0.8 \mathrm{~mol} / \mathrm{l})$ was added to a $0.2 \mathrm{M}$ solution of the monomer (aniline, $p$-phenylenediamine) and dissolved, and a $0.25 \mathrm{M}$ solution of ammonium peroxodisulphate was added. The polymeric reaction was complete within 24 hours. The product was filtered out, rinsed with $0.4 \mathrm{M}$ $\mathrm{H}_{3} \mathrm{PO}_{4}$ and acetone until the filtrate was perfectly clear, dried $60^{\circ} \mathrm{C}$ in a dryer and milled in the dry state.

The zinc ferrite powder was prepared by calcination of a $\mathrm{ZnO} / \mathrm{Fe}_{2} \mathrm{O}_{3} 1: 1$ mixture at $980{ }^{\circ} \mathrm{C}$ for 2 hours; this temperature was reached at the rate of $5{ }^{\circ} \mathrm{C}$ per minute. The ferritic pigments possessed different particle sizes: specularite (" $\mathrm{ZnFe}_{2} \mathrm{O}_{4}(\mathrm{~S})$ ") had lamellar particles, whereas hematite (" $\mathrm{ZnFe}_{2} \mathrm{O}_{4}(\mathrm{H})$ ") had spherical particles. The calcined powders were wet milled at $390 \mathrm{rpm}$ for 4.5 hours with a $30-$ min holdup and reverse run and then dried at $90^{\circ} \mathrm{C}$. The following pigment powder parameters were measured: density, oil absorption number (OA) by the mortar-and-pestle method (CSN 67 0351) for critical pigment volume concentration (CPVC) determination, $\mathrm{pH}$ of aqueous extracts during 28 days (ISO 787-9) followed by steel panel exposure to the extract and corrosion loss measurement as per CSN 673004 (Cor.L). The CPVC values were used when setting up a paint series with increasing ferritic pigment volume concentration (PVC), specifically PVC $=5 \%, 10 \%, 20 \%$ and $25 \%$, and a constant concentration of the conductive polymer (PANI, PPDA), viz. 3 wt.\%. Worlée Dur46 (nER brand) solvent-type epoxy-ester resin served as the paint binder. All the paints were completed with Plastorit silicate filler at $\mathrm{Q}=30 \%$. The paints were applied to low-carbon steel panels and glass panels by using a box-type slot ruler, providing a dry film thickness (DFT) about $100 \mu \mathrm{m}$. The DFT was controlled by applying a $\mathrm{TiO}_{2}+\mathrm{CaCO}_{3}$ top coat at $\mathrm{PVC}=12 \%$. A test cut $8 \mathrm{~cm}$ long was made through all the paint films as per ISO 12944-6 by using a knife as per ISO 2409 , blade width $0.5 \mathrm{~mm}$. The paint films were then subjected to a corrosion test by exposure to a wet atmosphere containing sulphur dioxide as per CSN 3231. The exposure time was 1008 hours. The first cycle phase, panel exposure to condensed water vapour containing $\mathrm{SO}_{2}$ at $(35 \pm 1)^{\circ} \mathrm{C}$ for 8 hours, was followed by the drying phase at $(23 \pm 1)^{\circ} \mathrm{C}$ for 16 hours. The corrosion phenomena were examined on the paint films as per ASTM D 714-78 (blistering on the paint film surface and in the test cut). Subsequently the paint film was removed and corrosion on the steel panel surface and in the test cut was assessed as per ASTM D 610-85 and ASTM D 1654-92, respectively.

\section{RESULTS AND DISCUSSION}

The pigments were characterised by their physicomechanical parameters. The powdered pigments were compared both with one another and, in particular, with a chromate reference sample (see Tab. 1).

Tab. 1. Characterization of pigment powders / Charakterizace pigmentových prášků

\begin{tabular}{|c|c|c|c|c|c|c|c|c|c|}
\hline & \multirow{2}{*}{$\rho\left(\mathrm{g} \mathrm{cm}^{-3}\right)$} & \multirow{2}{*}{ OA $\left(\mathrm{g} 100 \mathrm{~g}^{-1}\right)$} & \multirow{2}{*}{ CPVC } & \multirow{2}{*}{$W_{20}(\%)$} & \multirow{2}{*}{$W_{100}(\%)$} & \multirow{2}{*}{$\operatorname{Cor}_{\text {L }}(\%)$} & \multicolumn{3}{|c|}{$\mathbf{p H} \pm \mathbf{0 . 0 5}$} \\
\hline & & & & & & & day 7 & day 28 & remove \\
\hline PANI & 1.64 & 66 & 46 & 24.1 & 27.7 & 108 & 1.55 & 2.1 & 4.51 \\
\hline PPDA & 1.75 & 19 & 35 & 27.4 & 23.5 & 117 & 1.57 & 2.22 & 4.12 \\
\hline $\mathrm{ZnFe}_{2} \mathrm{O}_{4}(\mathrm{H})$ & 5.91 & 23 & 37 & 1.6 & 3 & 22 & 6.94 & 7.18 & 7.71 \\
\hline $\mathrm{ZnFe}_{2} \mathrm{O}_{4}(\mathrm{~S})$ & 5.8 & 9 & 67 & 1.6 & 0.6 & 26 & 10.61 & 8.1 & 7.91 \\
\hline $\mathrm{ZnO}$ & 5.94 & 11 & 58 & 0.7 & 0.1 & 0.2 & 5.45 & 6.1 & 5.58 \\
\hline Silicate filler & 3.47 & 33 & 51 & 0.9 & 1 & 8 & 5.72 & 7.12 & 8.25 \\
\hline Zinc chromate & 3.86 & 14 & 53 & 1.2 & 0.7 & 48 & 6.69 & 6.21 & 5.58 \\
\hline
\end{tabular}


The conductive polymers exhibited lower densities than the chromate (PANI $1.64 \mathrm{~g} \mathrm{~cm}^{-3}$; PPDA $1.78 \mathrm{~g} \mathrm{~cm}^{-3}$ ) whereas the ferritic pigments exhibited higher densities than the chromate $\left(\mathrm{ZnFe}_{2} \mathrm{O}_{4}(\mathrm{~S}) 5.91 \mathrm{~g} / \mathrm{cm}^{3} ; \mathrm{ZnFe}_{2} \mathrm{O}_{4}(\mathrm{H})\right.$ $\left.5.08 \mathrm{~g} / \mathrm{cm}^{3}\right)$. The quantities were characterised in order to enable the ingredients to be compared. While the use of PANI as the conductive polymer brought about increase in the specific surface area $(\mathrm{OA}=66 \mathrm{~g} / 100 \mathrm{~g}$ pigment), this effect was not observed with PPDA $(\mathrm{OA}=9 \mathrm{~g} / 100 \mathrm{~g}$ pigment $)$. This is the reason why the paint films exhibited larger blisters at a lower PVC when containing PANI than when containing PPDA, because the pigment adsorbed a fraction of the corrosive medium on its surface. The ferrites themselves differed mainly in the possibility of the maximum filling in the coating system $-\mathrm{ZnFe}_{2} \mathrm{O}_{4}(\mathrm{H}) 37 \%$ and $\mathrm{ZnFe}_{2} \mathrm{O}_{4}(\mathrm{~S}) 67 \%$. They also differed in the amounts of water-soluble substances and in the $\mathrm{pH}$ levels of their aqueous extracts. While no major difference was observed in the amounts of substances soluble in cold water $\left(\mathrm{W}_{20}\right)$, the difference in the amounts of substances soluble in hot water $\left(\mathrm{W}_{100}\right)$ was appreciable, $\mathrm{ZnFe}_{2} \mathrm{O}_{4}(\mathrm{~S})$ being the more stable of the two pigments $\left(\mathrm{W}_{100}=0.61 \%\right)$. This pigment was more stable at elevated temperatures, which makes it suitable for thermal stress conditions. The use of alkaline inhibiting soaps is beneficial as regards resistance to the corrosive environment and efficient steel panel protection. A higher alkalinity was more than desirable taking into account the combination of the ferritic pigment with the conductive polymer, which had to lie in the acid $\mathrm{pH}$ range for the desirable and required electrochemical mechanism of substrate metal protection to be ensured. In fact, the conductive polymer existed in the form of its conductive phosphate salt and its acidity had to be around $\mathrm{pH} 2$. This was met both for PANI ( $\mathrm{pH} 2.1$ ) and for PPDA (pH 2.22) on day 28. Although the initial $\mathrm{pH}$ value was high, it was shifted to the neutral range by the addition of the conductive polymer. Compared to chromate, whose $\mathrm{pH}$ was neutral during the entire period of measurement, it changed its behaviour only after the steel panel had been inserted and exposed to the aqueous extract. Its $\mathrm{pH}$ was shifted to the acid region, promoting the formation of corrosion products. The conductive polymers increased their $\mathrm{pH}$ by up to 2 units when the panel was submerged into their solutions, and the ferritic pigment maintained the steel panel in the neutral range. The aim of the work was to set up a mixed ferritic pigment containing a fraction of a conductive polymer, so the inhibiting and electrochemical mechanisms of steel panel protection are combined in the system. A paint series with increasing volume concentrations of the ferritic ingredient was set up with a view to finding the most efficient combination. This paint series was used in the laboratory corrosion test examining the resistance of the paint films to an environment of $100 \%$ condensed air humidity containing $\mathrm{SO}_{2}$ fog. The systems examined are listed in Tab. 2 .
The combination of $\mathrm{ZnFe}_{2} \mathrm{O}_{4}(\mathrm{~S})$ with PANI or PPDA put a stop to the formation of blisters on the paint film. With $\mathrm{ZnFe}_{2} \mathrm{O}_{4}(\mathrm{H})$, the $2 \mathrm{~F}$ type blisters continued to be formed despite the addition of the conductive polymer, which had no effect on the spherical shape of the hematite particles. The ferritic pigment combination with the conductive polymers reduced blisters in the test cut from the values of 2 to 6 or 4 , respectively, with increasing PVC. Appreciable improvement was observed in the fraction of the metallic substrate surface area affected by corrosion, which decreased with conductive polymer additions. PANI was superior to PPDA: the lowest corroded surface fraction when the conductive polymer was used in combination with $\mathrm{ZnFe}_{2} \mathrm{O}_{4}(\mathrm{~S})$ was $0.1 \%$ and $0.3 \%$ at $\mathrm{PVC}=5 \%$ and $10 \%$, respectively.

Improvement was also observed with $\mathrm{ZnFe}_{2} \mathrm{O}_{4}(\mathrm{H})$, where the addition of the conductive polymer reduced the corroded steel surface fraction from as much as $33 \%$ to mere $3 \%$. Homogenisation of the conductive polymer/ ferritic powder mixture brought about specific particle distribution in the paint. This is important with respect to the assessment of their behaviour in the paints. Two combinations appeared to be suitable for primers for steel materials. The $\mathrm{ZnFe}_{2} \mathrm{O}_{4}(\mathrm{H})$ spherical pigment type was appropriate for combination with PPDA. This was confirmed by the extent of corrosion in the test cut, which was lower with $\mathrm{ZnFe}_{2} \mathrm{O}_{4}(\mathrm{H})$ than with $\mathrm{ZnFe}_{2} \mathrm{O}_{4}(\mathrm{~S})$. Also, the values corresponded with the corrosion losses (Cor. ${ }_{\mathrm{L}}$ ), which were lowest, viz. $0.14 \%$, at $\mathrm{PVC}=5 \%$ and $10 \%$. The $\mathrm{ZnFe}_{2} \mathrm{O}_{4}(\mathrm{H}) / \mathrm{PPDA}$ system failed if the PVC level was increased to $25 \%$ (corrosion in the cut was $4.4 \mathrm{~mm}$ and the corroded metal surface fraction was $50 \%$ ) and the system was subject to self-destruction. This was in contrast to the $\mathrm{ZnFe}_{2} \mathrm{O}_{4}(\mathrm{~S}) / \mathrm{PPDA}$ system, which exhibited the lowest corrosion loss, $0.15 \%$, at $\mathrm{PVC}=25 \%$, corrosion in the cut was as low as $1.9 \mathrm{~mm}$ and the corroded metal fraction was reduced from $33 \%$ to $16 \%$. A similar bur reverse trend was observed with PANI. PANI combined well with $\mathrm{ZnFe}_{2} \mathrm{O}_{4}(\mathrm{~S})$ (having lamellar particles). At PVC $\leq 10 \%$, corrosion in the cut did not exceed $1.2 \mathrm{~mm}$, the corroded metal fraction did not exceed $0.3 \%$ and corrosion loss did not exceed $1.2 \%$. The combination with PANI ceased to be convenient as the PVC was additionally increased, the combination with $\mathrm{ZnFe}_{2} \mathrm{O}_{4}(\mathrm{H})$ providing more favourable results. The corrosion loss decreased, compared to $\mathrm{ZnFe}_{2} \mathrm{O}_{4}(\mathrm{~S})$, from $22 \%$ to $8 \%$. It can be concluded that the selection of the conductive polymer depends both on the particle shape and on a suitably selected concentration of the prevailing pigment. As to their mechanical properties, $\mathrm{ZnFe}_{2} \mathrm{O}_{4}(\mathrm{~S})$ was more resistant to mechanical stress than $\mathrm{ZnFe}_{2} \mathrm{O}_{4}(\mathrm{H})$. The paint films were more elastic. The paint films containing $\mathrm{ZnFe}_{2} \mathrm{O}_{4}(\mathrm{H})$ cracked on the impact of a weight (ISO 6272) because the pigment volume concentration $\mathrm{PVC}=25 \%$ approached the critical value of $\mathrm{CPVC}=37$. 
Tab. 2. Corrosive effects in $\mathrm{SO}_{2}$ mist environment (Both of type pigment are written in one line) / Korozni projevy v prostředi SO mlhy (oba typy pigmentů jsou psané v jednom řádku oddělené lomitkem)

\begin{tabular}{|c|c|c|c|c|c|c|c|}
\hline & \multirow{2}{*}{ PVC [\%] } & \multicolumn{2}{|c|}{ Blistering } & \multicolumn{2}{|c|}{ Corrosion } & \multirow{2}{*}{$\begin{array}{c}\text { Cut apper. } \\
\text { before (after) }\end{array}$} & \multirow{2}{*}{$\begin{array}{c}\text { Cor.loss } \\
{[\%]}\end{array}$} \\
\hline & & in area & in cut & in area & in cut & & \\
\hline \multicolumn{8}{|c|}{ Combination with SILICATE FILLER } \\
\hline \multirow{4}{*}{$\begin{array}{l}\mathrm{ZnFe}_{2} \mathrm{O}_{4}(\mathrm{~S}) / \\
/ \mathrm{ZnFe}_{2} \mathrm{O}_{4}(\mathrm{H})\end{array}$} & 5 &.$/ 2 \mathrm{~F}$ & $2 \mathrm{~F} / 2 \mathrm{M}$ & $3 / 0.3$ & $3.4 / 2.6$ & $1(4 a) / 2(2)$ & $14 / 14$ \\
\hline & 10 &.$/ 2 \mathrm{~F}$ & $2 \mathrm{~F} / 2 \mathrm{M}$ & $10 / 3$ & $3.4 / 2.3$ & $2(4 a) / 2(2)$ & $14 / 14$ \\
\hline & 20 & $6 \mathrm{~F} / 2 \mathrm{~F}$ & $4 \mathrm{M} / 4 \mathrm{M}$ & $50 / 33$ & $2.1 / 3.3$ & $2(1) / 3 b(3 a)$ & $56 / 16$ \\
\hline & 25 & $4 \mathrm{~F} / 2 \mathrm{~F}$ & $4 \mathrm{M} / 4 \mathrm{MD}$ & $50 / 33$ & $2.9 / 3.1$ & $2(2) / 2(3 a)$ & $5 / 14$ \\
\hline \multicolumn{8}{|c|}{ Combination with PPDA } \\
\hline \multirow{4}{*}{$\begin{array}{l}\mathrm{ZnFe}_{2} \mathrm{O}_{4}(\mathrm{~S}) / \\
/ \mathrm{ZnFe}_{2} \mathrm{O}_{4}(\mathrm{H})\end{array}$} & 5 &.$/ 2 \mathrm{~F}$ & $6 \mathrm{M} / 4 \mathrm{~F}$ & $3 / 1$ & $2.8 / 2.1$ & $2(3) / 1(2)$ & $11 / 0.14$ \\
\hline & 10 &.$/ 2 \mathrm{~F}$ & $6 \mathrm{~F} / 4 \mathrm{M}$ & $1 / 0.3$ & $2.8 / 2.9$ & $2(1) / 1(2)$ & $8 / 0.14$ \\
\hline & 20 &.$/ 4 \mathrm{~F}$ & $6 \mathrm{~F} / 4 \mathrm{M}$ & $33 / 3$ & $2.5 / 1.8$ & $1(3) / 2(2)$ & $13 / 7$ \\
\hline & 25 &.$/ 4 \mathrm{~F}$ & 4M/4MD & $16 / 50$ & $1.9 / 4.4$ & $2(3) / 3 a(2)$ & $0.15 / 155$ \\
\hline \multicolumn{8}{|c|}{ Combination with PANI } \\
\hline \multirow{4}{*}{$\begin{array}{l}\mathrm{ZnFe}_{2} \mathrm{O}_{4}(\mathrm{~S}) / \\
/ \mathrm{ZnFe}_{2} \mathrm{O}_{4}(\mathrm{H})\end{array}$} & 5 &.$/ 2 \mathrm{~F}$ & $4 \mathrm{M} / 4 \mathrm{M}$ & $0.1 / 3$ & $1.1 / 2.1$ & $2(4 a) / 2(3)$ & $0.15 / 18$ \\
\hline & 10 &.$/ 2 \mathrm{~F}$ & $6 \mathrm{M} / 6 \mathrm{M}$ & $0.3 / 1$ & $1.2 / 1.9$ & $1(4 a) / 1(3)$ & $1.2 / 12$ \\
\hline & 20 & $.2 \mathrm{~F}$ & $4 \mathrm{~F} / 6 \mathrm{M}$ & $10 / 3$ & $1.9 / 2.3$ & $2(4 a) / 1(3)$ & $14 / 10$ \\
\hline & 25 &.$/ 2 \mathrm{~F}$ & $4 \mathrm{~F} / 4 \mathrm{M}$ & $16 / 0.3$ & $2.3 / 1.9$ & $3 b(4 a) / 2(3)$ & $22 / 8$ \\
\hline \multicolumn{8}{|c|}{ Blanc sample } \\
\hline Zinc Chromate & 10 & $8 \mathrm{~F}$ & $2 \mathrm{~F}$ & 0.01 & 42860 & $3 a(3 a)$ & 0.68 \\
\hline \multicolumn{8}{|c|}{ Non-pigmented epoxy-ester resin } \\
\hline nER & 0 & $2 \mathrm{M}$ & $4 \mathrm{M}$ & 33 & 42858 & $2(2) / 2(2)$ & 10 \\
\hline
\end{tabular}

\section{CONCLUSION}

In conclusion, homogenisation of ferritic pigments with conductive polymers clearly improves their corrosion resistance to an industrial atmosphere containing $\mathrm{SO}_{2}$. The lamellar particle shape completely prevented the formation of blisters on the paint film surface while the spherical shape improved corrosion in the cut. Particle distribution in the paint film could be inferred from the particle size: particles of the conductive polymer filled the void space between the ferritic pigment particles, thereby preventing penetration of the corrosive medium to the substrate metal, and provided a synergistic anticorrosion protection effect supported by the barrier effect of the topcoat.

\section{REFERENCES}

1. Schauer T. et al. Protection of iron against corrosion with polyaniline primers, Progress in Organic Coatings 1998, 33, 20-27.

2. Armelin E. et al. Corrosion protection with polyaniline and polypyrrole as anticorrosive additives for epoxy paint, Corrossion Science 2008, 50, 721-728.
3. Yang X. et al. Anticorrosion performance of polyaniline nanostructures on mild steel, Progress in Organic Coatings 2010, 69, 267-271.

4. Ebrahimi G. et al. Investigation on corrosion protection mechanism of polyaniline nanoparticles doped with phosphoric acid by scanning Kelvin probe and other electrochemical methods, Journal of Taiwan Institute. Chemical Engeniering 2017, 70, 427-436.

5. Kalendová A., Kalenda P. Antikorozní nátěrové hmoty ve vícevrstvých systémech, Corrosion and Protection of Materials 1994, 38 (5), 81-89.

6. Kalendová A., Antoš P. Anticorrosive coatings in multilayer systems, Corrosion and Protection of Materials 1998, 42, 55-57.

7. Kalendová A. Alkalising and neutralising effects of anticorrosive pigments containing $\mathrm{Zn}, \mathrm{Mg}, \mathrm{Ca}$, and $\mathrm{Sr}$ cations, Progress in Organic Coatings 2000, 38, 199-206.

8. Kurian M., Nair D. S. Effect of preparation conditions on Nickel Zinc Ferrite nanoparticles: A comparison between sol-gel auto combustion and co-precipitation methods, Journal of Saudi Chemical Society 2016, 20, S517-S522.

9. Armelin E. Anticorrosion performances of epoxy coatings modified with polyaniline: A comparison between the emeraldine base and salt forms, Progress in Organic Coatings 2009, 65, 88-93.

10. Alam J. High performance corrosion resistant polyaniline/ alkyd ecofriendly coatings, Current Applied Physics 2009, $9,80-86$. 